\title{
PENGARUH MEKANISME GOOD CORPORATE GOVERNANCE TERHADAP MANAJEMEN LABA
}

\author{
Yusuf Mangkusuryo, A. Waluyo Jati \\ Prodi Akuntansi FEB Universitas Muhammadiyah Malang \\ Jl. Raya Tlogomas No. 246 Malang \\ Email: mangkusuryo@gmail.com
}

\begin{abstract}
This study aimed to determine the effect of Good Corporate Governance mechanism toward earnings management that is proxied with discretionary accruals (DTA). The GCG mechanism is proxied with managerial ownership (KM), institutional leadership (KI), independent board of commissioner (DKI) and independent audit committee (KAI). The sample used in this study were 11 companies registered in CGPI for three years starting from 2013 to 2015.To know whether the above GCG variables have an effect on earnings management, multiple linear regression test using SPSS 2.1 program. The test results show that only managerial ownership variables has significantly influence to earnings management. While other variables such as institutional ownership (KI), independent board of commissioner (DKI), and independent audit committee (KAI) have no significant effect to earnings management.
\end{abstract}

Keyword: Good Corporate Governance, managerial ownership, institusional leadership, independent board of commisioner, independent audit committee, earning management.

\section{PENDAHULUAN}

Istilah Good Corporate Governance (GCG) pertama kali diperkenalkan pada tahun 1992 oleh Komite Cadbury dalam laporannya, yang dikenal sebagai Laporan Cadbury. Menurut Komite Cadbury pada tata kelola perusahaan adalah prinsip langsung mengendalikan perusahaan agar mencapai keseimbangan antara kekuatan dan kewenangan perusahaan dalam memberikan pertanggungjawaban kepada pemegang saham pada khususnya, dan stakeholder. Tata Kelola Perusahaan yang baik merupakan sarana atau mekanisme untuk memberikan jaminan kepada investor dalam memperoleh pengembalian yang tepat untuk investasi yang telah ditanam (Komite Cadbury, 1992).

Sementara Forum of Corporate Governance for Indonesia-FCGI (2001) mengemukakan bahwa corporate governance adalah seperangkat peraturan yang mengatur hubungan (dengan kata lain sebagai system yang mengendalikan perusahaan) antara pemegang saham, pengurus (pengelola) perusahaan, pihak kreditur, pemerintah, karyawan serta pemegang kepentingan internal dan eksternal lainnya yang berkaitan dengan hak-hak dan kewajiban mereka. Dengan penerapan Corporate Governance akan dapat mendatangkan banyak manfaat dan keuntungan bagi perusahaan terkait dan juga pihak-pihak lain yang berhubungan langsung dan tidak langsung terhadap perusahaan.

Chotourou et al. (2001) dalam penelitiannya mendukung pernyataan yang diusulkan oleh berbagai badan independen (Joint Committe on Corporate Governance 2001; SEC 2000; BRC 1999; Cadbury Committe 1992) tidak hanya mengurangi kecurangan dalam pelaporan keuangan tetapi juga mengurangi kemungkinan dari praktik manajemen laba, dimana laporan penghasilan lebih mencerminkan keinginan manajemen dari pada kinerja keuangan yang men-

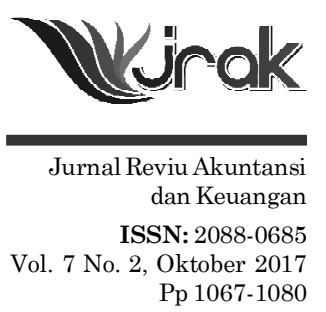


Pengaruh

Mekanisme

Good

Corporate...

1068 dasari. Chtourou dkk (2001) menjelaskan lebih lanjut bahwa penerapan prinsipprinsip corporate governance yang konsisten akan menghalangi kemungkinan dilakukannya rekayasa kinerja (earnings management) yang mengakibatkan nilai fundamental perusahaan tidak tergambar dalam laporan keuangannya.

Penelitian ini mereplikasi penelitian yang dilakukan oleh Hazri dan Sugiarti (2012) dengan objek penelitian perusahaan yang masuk dalam Corporate Governance Perception Index (CGPI) tahun 2006-2008 yaitu daftar yang dibuat oleh The Indonesian Institute of Corporate Governance (IICG). Pemilihan sampel tersebut dalam penelitian ini karena perusahaan yang terdaftar di CGPI karena perusahaan tersebut memiliki komitmen serta mendapat pelatihan penerapan GCG dari lembaga independen yang memiliki pemahaman yang baik terhadap penerapan GCG yang berkualitas.

\section{TINJAUAN PUSTAKA DAN PERUMUSAN HIPOTESIS}

\section{Teori Agensi}

Dalam penelitian Borlea dan Monica (2013), Teori ini mengacu pada hubungan yang terjalin antara pemilik perusahaan (principal) dan direksi (agent). Hubungan yang tercipta antara agent dan principal, diwujudkan dengan melakukan kontrak berupa pihak satu (principal) memberikan amanat pada pihak (agent) untuk melaksanakan beberapa layanan atas nama mereka (principal).

\section{Teori Moral Hazard}

Adanya konflik kepentingan agent dan principal menyebabkan munculnya asumsi bahwa setiap individu cenderung untuk bertindak mementingkan kepentingannya sendiri (oportunistis). Sehingga mendorong agent untuk menyembunyikan dan menyajikan informasi yang tidak sebenarnya kepada principal (Borlea dan Monica, 2013).

\section{Teori Asimetri Informasi}

Hipotesis mengenai asimetri informasi berkaitan erat dengan agency theory dan adanya hubungan keagenan. Asumsi yang menyatakan bahwa agent memiliki informasi yang lebih dibandingkan principal mengakibatkan agent memanfaatkan asimetri informasi untuk menyembunyikan informasi yang tidak menguntungkan dan hanya menyajikan informasi sesuai keinginannya terutama informasi yang menilai kinerja dari manajemen.

\section{Manajemen Laba}

Secara umum manajemen laba adalah suatu tindakan mempengaruhi laba (income) yang dilakukan secara sengaja oleh manajemen suatu perusahaan yang memiliki informasi mengenai keuntungan ekonomis yang secara real atau nyata tidak terjadi pada laporan keuangan perusahaan tersebut dan pada akhirnya akan menyebabkan ketidak jelasan dan hilangnya kepercayaan parapemegang saham maupun stakeholders, sehingga akan berujung pada kerugian perusahaan (Hanif, 2009 dalam penelitian Hazri \& Sugiyarti 2011).

\section{Teori Stakeholder}

Dalam penelitian Borlea dan Monica (2013), menyatakan istilah "stakeholder" mengacu pada semua orang, kelompok, atau organisasi yang memiliki dampak pada aktivitas perusahaan atau dipengaruhi oleh perusahaan. Yaitu: pemilik, pesaing, pemerintah, pemerintah daerah, LSM, kelompok penekan, masyarakat, 
media dan sebagainya. Masing-masing bagian ini entah bagaimana berinteraksi dan mempengaruhi bisnis perusahaan.

\section{Good Corporate Governance}

Istilah GCG pertama kali diperkenalkan oleh Komite Cadbury pada tahun 1992 dalam laporannya yang disebut sebagai Cadbury Report, menjelaskan bahwa Good Corporatate Governance adalah sistem yang mengarahkan dan mengendalikan perusahaan dalam memberikan pertanggungjawaban kepada pemegang saham pada khususnya dan pemangku kepentingan (Tanjung et al, 2015). Tim GCG BPKP mendefinisikan GCG dari segi soft definition yang mudah dicerna sekalipun orang awam yaitu "komitmen, aturan main, serta praktik penyelenggaraan bisnis secara sehat dan beretika". Dalam Forum for Corporate Governance in Indonesia (FCGI), menjelaskan lebih lanjut GCG sebagai: seperangkat aturan yang menentukan hubungan antara pemegang saham, manajer, kreditor, pemerintah, karyawan dan pemangku kepentingan internal dan eksternal lainnya sehubungan dengan hak dan tanggung jawab mereka, atau sistem dimana perusahaan diarahkan dan Dikendalikan. Tujuan GCG adalah untuk menciptakan nilai tambah perusahaan bagi pemangku kepentingan.

\section{Kepemilikan Manajerial}

Kepemilikan Manajerial (KM) merupakan saham yang dimiliki oleh manajemen secara pribadi maupun saham yang dimiliki oleh anak cabang. Perusahaan bersangkutan beserta afiliasinya, (Susiana \& Herawaty 2007 dalam penelitian Sari 2013). Pengukuran variabel KM menggunakan skala rasio, berikut rumus pengukuran variabel tersebut:

$\mathrm{H}_{1}$ : Kepemilikan manajerial berpengaruh signifikan terhadap manajemen laba.

\section{Kepemilkan Institusional}

Teori keagenan menunjukkan bahwa pemantauan oleh kepemilikan institusional dapat menjadi tata kelola yang penting bagi perusahaan. Selain itu, investor institusi memiliki kesempatan, sumber daya, dan kemampuan untuk memonitor manajer. Oleh karena itu, kepemilikan institusional berhubungan dengan pemantauan yang lebih baik dari kegiatan manajemen, mengurangi kemampuan oportunistik manajer untuk memanipulasi laba (Kazemian \& Sanusi, 2015).

$\mathrm{H}_{2}$ : Kepemilikan institusional berpengaruh signifikan terhadap manajemen laba.

\section{Dewan Komisaris}

Dalam Peraturan OJK Nomor 33/POJK.04/2014, Dewan Komisaris adalah organ perusahaan bertugas melakukan pengawasan dan bertanggung jawab atas pengawasan terhadap kebijakan pengurusan, jalannya pengurusan pada umumnya, baik mengenai Perusahaan Publik, dan memberi nasihat kepada direksi. Sehingga peran dewan komisaris diharapkan dapat mengurangi praktik manajemen laba.

$\mathrm{H}_{3}$ : Dewan komisaris independen berpengaruh signifikan terhadap manajemen laba

\section{Komite Audit Independen}

Peraturan OJK 55/POJK.04/2015, menyatakan bahwa dalam rangka mendukung efektivitas pelaksanaan tugas dan tanggung jawabnya, dewan komisaris wajib membentuk dewan komite audit. Peran komite audit adalah memeriksa, menyarankan dan mengawasi informasi keuangan perusahaan yang akan di- 
Pengaruh Mekanisme Good Corporate... 1070 publikasikan terkait ketaatan terhadap peraturan perundang-undangan. Dengan peran tersebut diharapkan dapat meminimalisir perilaku oportunistik manajemen. $\mathrm{H}_{4}$ : Komite audit independen bepengaruh signifikan terhadap manajemen laba

Berdasarkan penjelasan di atas, maka rerangka pemikiran dapat digambarkan dalam bagan sebagai berikut:

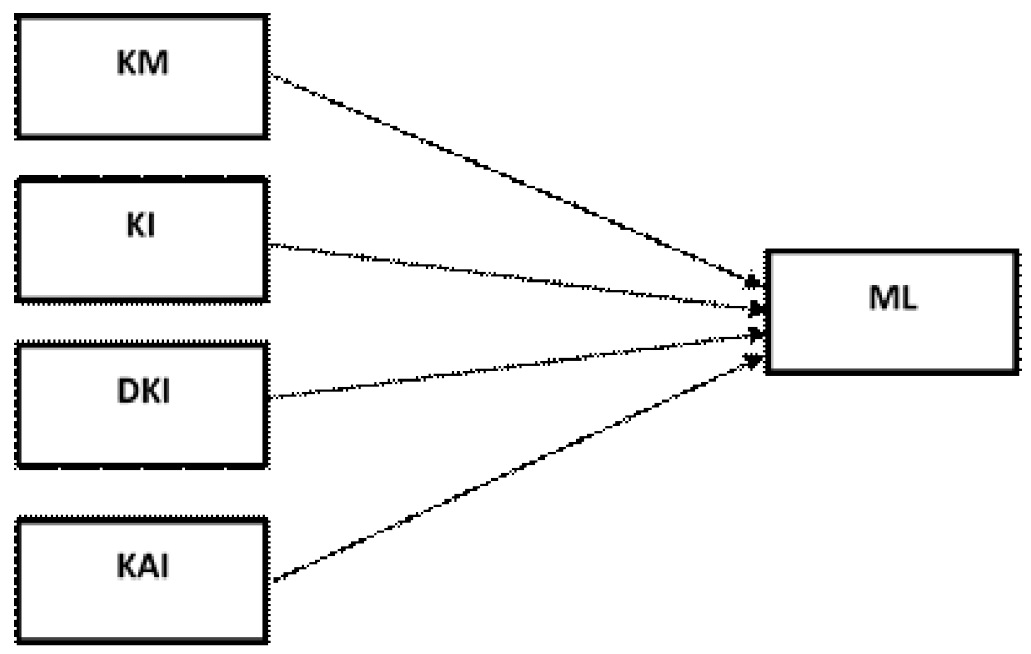

Sumber: pemikiran sendiri

\section{METODE PENELITIAN}

Lokasi penelitian ini berada di Bursa Efek Indonesia (BEI) untuk mendapatkan data laporan keuangan perusahaan periode 2013-2015 yang dapat diakses melalui website www.idx.co.id. Sampel penelitian ini dipilih menggunakan purposive sampling method.

Perusahaan yang masuk dalam daftar Corporate Governance Perception Index (CGPI) yang dipilih berdasarkan hasil penilaian The Indonesian Institute for Corporate Governance (IICG), perusahaan juga harus ada dalam daftar CGPI mulai tahun 2013-2015 dan perusahaan itu bukan lembaga keuangan.

Discretionary accruals merupakan selisih antara total accruals dan nondiscretionary accruals. Sedangkan total accruals merupakan selisih antara net income dan cash flow from operations. Total akrual dipecah menjadi komponen discretionary accruals dan nondiscretionary accruals dengan menggunakan modified Jones model, (Dechow et al 1995 dalam penelitian Sulistyanto dan Haris, 2003).

Dalam Penelitian ini menggunakan discretionary total accruals(DTA) sebagai proksi rekayasa keuangan yang dilakukan manajemen.Untuk mengukur DTA, terlebih dahulu akan mengukur total akrual. Total akrual diklasifikasikan menjadi komponen discretionary dan nondiscretionary (Midiastuty, 2003), dengan tahapan:

a. Mengukur total accrual dengan menggunakan model Jones yang dimodifikasi.

Total Accrual $(\mathrm{TAC})=$ laba bersih setelah pajak (net income) - arus kas operasi (cash flow from operating).

b. Menghitung nilai accruals yang diestimasi dengan persamaan regresi OLS (Ordinary Least Square):

$\mathrm{TAC}_{\mathrm{t}} / \mathrm{A}_{\mathrm{t}-1}=\alpha_{1}\left(1 / \mathrm{A}_{\mathrm{t}-1}\right)+\alpha_{2}\left(\left(\Delta \mathrm{REV}_{\mathrm{t}}-\Delta \mathrm{REC}_{\mathrm{t}}\right) / \mathrm{A}_{\mathrm{t}-1}\right)+\alpha_{3}\left(\mathrm{PPE}_{\mathrm{t}} / \mathrm{A}_{\mathrm{t}-1}\right)+$

Dimana:

$\mathrm{TAC}_{\mathrm{t}}$ total accruals perusahaan i pada periode $\mathrm{t}$

$\mathrm{A}_{\mathrm{t}-1 \mathrm{i}}$ total aset untuk sampel perusahaan i pada akhit tahun $\mathrm{t}-1$ 
$\mathrm{REV}_{\mathrm{t}}$ perubahan pendapatan perusahaan i dari tahun $\mathrm{t}-1$ ke tahun $\mathrm{t}$

$\mathrm{REC}_{\mathrm{t} \text { : }}$ perubahan piutang perusahaan i dari tahun $\mathrm{t}-1$ ke tahun $\mathrm{t}$

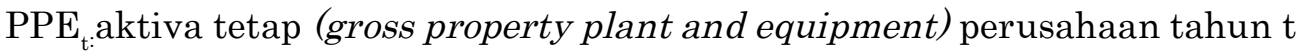

c. Menghitung nondiscretionary accruals model (NDA) adalah sebagai berikut:

$\mathrm{NDAt}=\alpha_{1}\left(1 / \mathrm{A}_{\mathrm{t}-1}\right)+\alpha_{2}\left(\left(\Delta \mathrm{REV}_{\mathrm{t}}-\Delta \mathrm{REC}_{\mathrm{t}}\right) / \mathrm{A}_{\mathrm{t}-1}\right)+\alpha_{3}\left(\mathrm{PPE}_{\mathrm{t}} / \mathrm{A}_{\mathrm{t}-1}\right.$

Dimana:

NDAt: nondiscretionary accruals pada tahun $\mathrm{t}$

$\alpha$ : fitted coefficient yang diperoleh dari hasil regresi pada perhitungan total accruals

d. Menghitung discretionary accruals

DACt: $\left(\mathrm{TAC}_{\mathrm{t}} / \mathrm{A}_{\mathrm{t}-1}\right)-\mathrm{NDA}_{\mathrm{t}}$

Dimana:

DACt: discretionary accruals perusahaan i pada periode $t$.

Kepemilikan Manajerial (KM) merupakan saham yang dimiliki oleh manajemen secara pribadi maupun saham yang dimiliki oleh anak cabang. Perusahaan bersangkutan beserta afiliasinya, (Susiana \& Herawaty 2007 dalam penelitian Sari 2013). Pengukuran variabel KM menggunakan skala rasio, berikut rumus pengukuran variabel tersebut:

$$
K M=\frac{\text { Jumlah saham yang dimiliki manajer }}{\text { Jumlah saham yang beredar di perusahaan }} \times 100 \%
$$

Kepemilikan institusional diukur dari jumlah persentase hak suara yang dimiliki institusi atau perusahaan. Indikator yang digunakan untuk mengukur kepemilikan institusional ini adalah persentase jumlah saham yang dimiliki oleh institusi terhadap seluruh modal saham yang beredar, berikut rumus pengukuran variabel tersebut:

$$
K I=\frac{\text { Jumlah saham yang dimiliki institusi }}{\text { Jumlah saham yang beredar di perusahaan }} \times 100 \%
$$

Komisaris Independen diukur menggunakan skala rasio melalui presentase anggota dewan komisaris yang berasal dari luar perusahaan dari seluruh ukuran anggota dewan komisaris perusahaan, (Isnanta 2008 dalam penelitian Herawaty 2010).Berikut rumus pengukuran variabel tersebut:

$$
K I=\frac{\text { Jumlah ang gota dewan komisaris di luar perusahaan }}{\text { Jumlah seluruh anggota dewan komisaris di perusahaan }}
$$

Komposisi Komite Audit menurut Peraturan tersebut keanggotaan yang bersifat independen dan tidak memiliki hubungan dengan perusahaan (dewan komisaris, direksi dan pemilik saham) kecuali dewan komisaris independen, sehingga perhitungan variabel KM dengan menggunakan skala rasio ditentukan dengan rumus sebagai berikut:

$$
K A=\frac{\text { Jumlah anggota komite audit independen dan dari luar emiten }}{\text { Jumlah seluruh anggota komite audit }}
$$

Penelitian ini bertujuan untuk menguji pengaruh kepemilikan manajerial, kepemilkan institusional, dewan komisaris independen dan komite audit independen sebagai proksi GCG terhadap manajemen laba yang diproksikan dengan discretionarry accruals. Pengujian dalam penelitian ini menggunakan program SPSS 2.1, berikut tahapan analisis data: 


\section{Pengaruh \\ Mekanisme \\ Good \\ Corporate...}

1072
1. Analisis Statistik Deskriptif, merupakan teknik deskriptif yang memberikan informasi mengenai data yang dimiliki dan tidak bermaksud menguji hipotesis. Analisis ini hanya digunakan untuk menyajikan dan menganalisis data disertai dengan perhitungan agar dapat memperjelas keadaan atau karakteristik data yang bersangkutan, Nurgiyantoro et al (2004) dalam Ningsaptiti (2010). Pengukuran yang digunakan dalam penelitian ini adalah mean, standar deviasi, maksimum, dan minimum.

2. Asumsi Klasik, digunakan untuk mengetahui apakah data tersebut memenuhi asumsi-asumsi dasar. Hal ini penting dilakukan untuk menghindari estimasi yang bias. Pengujian yang dilakukan dalam penelitian ini adalah Uji Normalitas, Uji Heteroskedastisitas, Uji Multikolinearitas, dan Uji Autokolerasi.

3. Analisis Regresi Linier Berganda,metode analisis yang digunakan untuk menilai variabilitas luas pengungkapan risiko dalam penelitian ini adalah analisis regresi berganda (multiple regression analysis). Analisis regresi berganda digunakan untuk menguji pengaruh variabel independen tingkat risiko perusahaan, ukuran perusahaan, dan jenis industri terhadap variabel dependen pengungkapan risiko perusahaan.

a. Pengujian Hipotesis, Koefisien Determinasi $\left(R^{2}\right)$ digunakan untuk mengukur seberapa jauh kemampuan variabel-variabel dependen. Nilai koefisien determinasi $\left(R^{2}\right)$ adalah antara nol dan satu. Nilai $R^{2}$ yang kecil berarti kemampuan variabel-variabel independen dalam menjelaskan variabel dependen amat terbatas. Jika koefisien determinasi sama dengan nol, maka variabel independen tidak berpengaruh terhadap variabel dependen. Jika besarnya koefisien determinasi mendekati angka 1, maka variabel independen berpengaruh sempurna terhadap variabel dependen. Dengan menggunakan model ini, maka kesalahan penganggu diusahakan minimum sehingga $R^{2}$ mendekati 1, sehingga perkiraan regresi akan lebih mendekati keadaan yang sebenarnya.

b. Uji Signifikansi Simultan (Uji Statistik F) Uji statistik F digunakan untuk mengetahui apakah semua variabel independen yang dimasukkan dalam model regresi mempunyai pengaruh secara bersama-sama (simultan) terhadap variabel dependen (Ghozali, 2006). Apabila nilai probabilitas signifikansi $<0.05$, maka variabel independen secara bersama-sama mempengaruhi variabel dependen.

c. Uji Signifikansi Parameter Individual (Uji Statistik T) Uji statistik t digunakan untuk mengetahui seberapa jauh pengaruh satu variabel independen secara individual dalam menjelaskan variasi variabel dependen (Ghozali, 2006). Apabila nilai probabilitas signifikansi $<0.05$, maka suatu variabel independen merupakan penjelas yang signifikan terhadap variabel dependen.

\section{HASIL PENELITIAN DAN PEMBAHASAN}

\section{Analisis Statistik Deskriptif}

\begin{tabular}{lcrrrrr}
\hline & N & Mean & Median & $\begin{array}{c}\text { Standar } \\
\text { Deviasi }\end{array}$ & Minimum & Maximum \\
\hline DAT & 33 & -0.08963 & -0.09334 & 0.18491 & -0.56308 & 0.39628 \\
KM & 33 & 0.00872 & 0.00003 & 0.02762 & 0 & 0.09473 \\
KI & 33 & 0.32354 & 0.30466 & 0.11034 & 0.09515 & 0.4832 \\
DKI & 33 & 0.36706 & 0.33333 & 0.06436 & 0.28571 & 0.5 \\
KAI & 33 & 0.84257 & 0.83333 & 0.14298 & 0.5 & 1 \\
\hline
\end{tabular}

Sumber: Data sekunder yang diolah, 2017 
Berdasarkan table 1 diatas menunjukkan variable dependen manajemen laba yang diproksikan dengan discretionary accruals (DAT) memiliki rata-rata 0.08963 yang berarti rata-rata perusahaan melakukan penurunan laba(income decreasing) sebesar 8.96\%.

Variabel independen mekanisme good corporate governance yang diproksikan dengan kepemilkan manajerial (KM), kepemilikan institusional (KI), dewan komisaris indpenden (DKI) dan komite audit independen (KAI). Pertama KM memiliki rata-rata 0.00872 yang berarti kepemilikan manajerial rata-rata sebesar $0.87 \%$ dan dengan nilai DKI minimum sebesar 0 atau $0 \%$.

Pengukuran mekanisme GCG kedua adalah kepemilikan Institusional (KI) dengan nilai rata-rata 0.32354 menunjukkan kepemilkan institusional dalam perusahaan sampel sangat tinggi yaitu sebesar $32.35 \%$.

Pengukuran mekanisme GCG ketiga adalah keberadaan dewan komisaris independen (DKI) dengan rata-rata 0.36706 atau sebsar $36.71 \%$ yang menunjukkan rata-rata perusahaan sampel telah memenuhi peraturan minimal DKI tidak kurang dari $30 \%$.

Pegukuran mekanisme GCG keempat yaitu komite audit independen (KAI) dengan nilai rata-rata 0.84257 yang berarti keberadaan audit independen sebesar $84.26 \%$ dari seluruh anggota komite audit dalam rata-rata perusahaan sampel. Variabel KAI memiliki nilai maksimum sebesar 1 yang berarti $100 \%$ seluruh anggota komite audit berasal dari luar perusahaan atau independen.

\section{Uji Asumsi Klasik}

a. Uji Normalitas
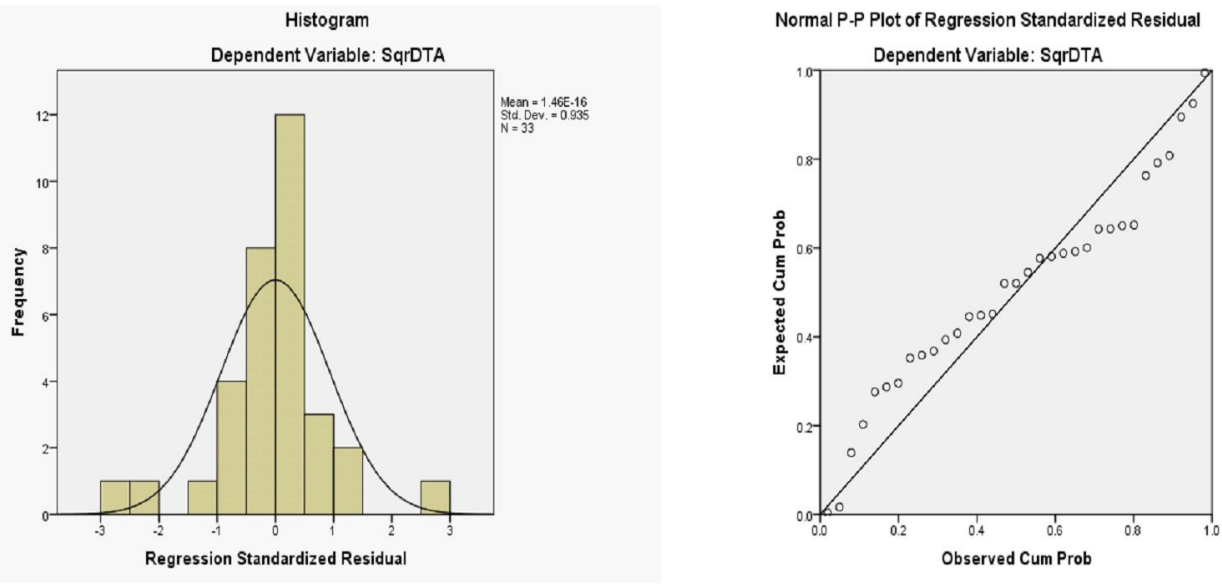

Sumber: Data sekunder yang diolah, 2017

Dan dari hasil pengujian dengan menggunakan analisis grafik histogram menunjukkan bahwa grafik histogram tidak condong ke kanan ataupun condong ke kiri maka dapat dikatakan data memiliki distribusi normal

\begin{tabular}{ccc}
\hline Kolmogorov-Smirnov Z & Nilai sig. & Keterangan \\
\hline 0.882 & 0.396 & Menyebar normal \\
\hline
\end{tabular}

Tabel 2

Tabel Kolmogorov-

Smirnov

Sumber: Data sekunder yang diolah, 2017

Besarnya nilai Kolmogorov-Smirnov Z adalah 0.882 dan tidak signifikan pada 0.05. Hal ini berarti H0 diterima yang berarti data residual terdistribusi normal dan model regresi layak untuk dipakai dalam penelitian ini. 


\section{Pengaruh Mekanisme Good Corporate...} 1074

Tabel 3

Hasil Uji Multikolonieritas

Gambar 2 Grafik Scatterplot

Tabel 4 Hsil Uji Autokolerasi dengan DurbinWatson (DW Test) b. Uji Multikoloniearitas

\begin{tabular}{llll}
\hline & Tolerance & VIF & Keterangan \\
\hline KM & 0.803 & 1.245 & Tidak terjadi Multikolonieritas \\
DK & 0.849 & 1.178 & Tidak terjadi Multikolonieritas \\
KI & 0.845 & 1.183 & Tidak terjadi Multikolonieritas \\
KM & 0.790 & 1.265 & Tidak terjadi Multikolonieritas \\
\hline
\end{tabular}

Sumber: Data sekunder yang diolah, 2017

Dari hasil outputdiatas menunjukkan bahwa nilai tolerance dari setiap variabel independen lebih dari 0.10 dan nilai VIF dari masing-masing variabel independen tidak lebih dari 10. Maka dapat disimpulkan tidak ada multikolonieritas antar variabel independen dari model regresi.

c. Uji Heteroskedastisitas

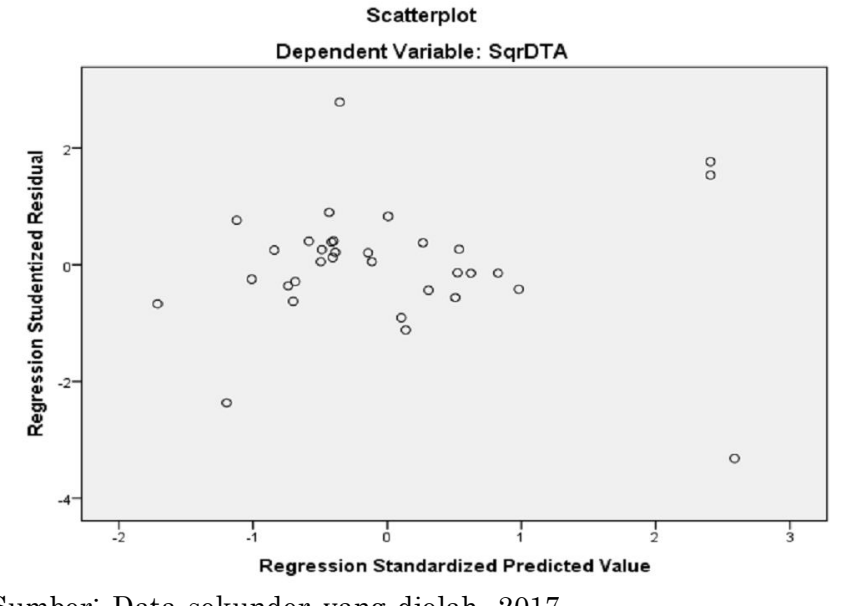

Sumber: Data sekunder yang diolah, 2017

Dari grafik scatterplot terlihat titik menyebar secara acak serta tersebar baik di atas maupun di bawah angka 0 pada sumbu Y. Hal ini dapat disimpulkan bahwa tidak terjadi heteroskedastisitas pada model regresi, sehingga model regresi layak dipakai untuk memprediksi setiap variabel dependen berdasarkan variabel-variabel independen.

d. Uji Autokorelasi

\begin{tabular}{|c|c|c|c|}
\hline $\mathrm{du}$ & $4-d u$ & $d w$ & interpretasi \\
\hline 1.730 & 2.270 & 2.048 & $\begin{array}{l}\text { Tidak terjadi } \\
\text { autokolerasi }\end{array}$ \\
\hline
\end{tabular}

Sumber: Data sekunder yang diolah, 2017

Dari hasil pengujian statistik nilai Durbin-Watson sebesar $2.048(d u=1.730$; $4 d u=2.270$ ). Hal ini berarti dalam model regresi tidak terdapat problem autokolerasi yang ditunjukkan dengan nilai Durbin-Watson berada di antara du tabel dan (4du tabel) sehingga $1.730<2.048<2.270$.

\section{Uji Regresi Linier Berganda}

\begin{tabular}{lccccc}
\multicolumn{7}{c}{ Coefficients $^{\mathbf{a}}$} \\
\hline \multirow{2}{*}{ Model } & \multicolumn{2}{c}{ Unstandardized Coefficients } & $\begin{array}{c}\text { Standardized } \\
\text { Coefficients }\end{array}$ & T & Sig. \\
\cline { 2 - 4 } & B & Std. Error & Beta & & \\
\hline (Constant) & 0,354 & 0.290 & & 1,221 & 0,232 \\
KM & 3,782 & 1.169 & 0,565 & 3,236 & 0,003 \\
KI & $-0,438$ & 0.285 & $-0,262$ & $-1,540$ & 0,135 \\
DKI & $-0,378$ & 0.489 & $-0,132$ & $-0,773$ & 0,446 \\
KAI & $-0,233$ & 0.228 & $-0,180$ & $-1,022$ & 0,315 \\
\hline
\end{tabular}


Dari hasil diatas dapat diketahui bahwa kepemilikan instituional (KI), dewan komisaris independen (DKI) dan komite audit independen (KAI) memilki pengaruh kearah negatif terhadap discretionary accruals (manajemen laba). Sedangkan kepemilkan manajerial (KM) memiliki pengaruh kearah positif terhadap manajemen laba.

\section{Hasil Uji Hipotesis}

a. Uji Koefisiensi Determinasi $\left(\mathrm{R}^{2}\right)$

\begin{tabular}{ccccc}
\hline Model & $\mathbf{R}$ & R Square & $\begin{array}{c}\text { Adjusted R } \\
\text { Square }\end{array}$ & $\begin{array}{c}\text { Std. Error of the } \\
\text { Estimate }\end{array}$ \\
\hline 1 & 0,561 & 0,315 & 0,217 & 0,163630337131609 \\
\hline
\end{tabular}

Tabel 6

Hasil Uji Koefisien

Determinasi

Sumber: Data sekunder yang diolah, 2017

Dari hasil output diatas dapat dilihat bahwa nilai Adjusted $R$ Square yang dihasilkan sebesar 0.217 yang berarti bahwa pengaruh variabel independen kepemilkan manajerial (KM), kepemilkan institusional (KI), dewan komisaris independen (DKI) dan komite audit independen (KAI) terhadap variabel dependen manajemen laba (KM) adalah sebesar $21.7 \%$ dan sisanya $78.3 \%$ dipengaruhi oleh variabel lain di luar model penelitian ini.

b. Uji Signifikansi Simultan (Uji Statistik F)

\begin{tabular}{cccc}
\hline Model & Mean Square & F & Sig. \\
\hline Regresion & 0,086 & 3,216 & 0,027 \\
Residual & 0,027 & & \\
\hline
\end{tabular}

Tabel 7

Hasil Uji Simultan (Uji F)

Sumber: Data sekunder yang diolah, 2017

Dari uji f didapat nilai $\mathrm{F}$ hitung sebesar 3.216 dengan signifikansi 0.024. Nilai Ftabel dengan df 4 dan df1 33 pada taraf nyata 5\% sebesar 2,660. Karena F hitung $>$ F tabel $(3.216>2.660)$ dan nilai signifikan $\mathrm{F}(0.027<0.05)$ maka dapat disimpulkan model regresi dapat digunakan untuk memprediksi discretionary accruals atau dapat dikatakan variabel independen secara bersama-sama berpengaruh terhadap manajemen laba.

c. Uji Signifikansi Parameter Individual (Uji Statistik t)

Analisis uji t digunakan untuk mengetahui besarnya pengaruh masing-masing variabel independen yaitu kepemilkan manajerial, kepemilkan institusional, dewan komisaris independen dan komite audit independen terhadap variabel dependen manajemen laba. Hasil uji t dapat dilihat pada tabel 4.7 berikut ini:

\begin{tabular}{cccccc}
\hline $\begin{array}{c}\text { Variabel } \\
\text { Bebas }\end{array}$ & Beta & t hitung & Sig. & t tabel & Keterangan \\
\hline KM & 3.782 & 3.236 & 0.03 & 1.701 & Berpengaruh \\
KI & -0.438 & -1540 & 0.135 & 1.701 & Tdk berpengaruh \\
DKI & -0.378 & -0.733 & 0.446 & 1.701 & Tdk berpengaruh \\
KAI & -0.233 & -1.022 & 0.315 & 1.701 & Tdk berpengaruh \\
\hline
\end{tabular}

Tabel 8

Hasil Uji Hipotesis

Parsial t

Sumber: Data sekunder yang diolah, 2017

Berdasarkan hasil analisis diatas maka diperoleh hasil uji hipotesis dengan 4 hipotesis sebagai berikut: 
Pengaruh

Mekanisme

Good

Corporate...

1076

\section{PEMBAHASAN}

\section{Pengaruh Kepemilikan Manajerial Terhadap Manajemen Laba}

Hasil analsis regresi linier berganda diperoleh beta sebesar 3.782 dengan sebesar 3.236 dan nilai signifikansi sebesar 0.003. Dari hasil $\left|t_{\text {hitung }}\right|>t_{\text {tabel }}(3.236>$ 1.701) dengan nilai signifikansi $<5 \%(0.003<0.05)$, maka dapat diartikan bahwa variabel kepemilikan manajerial secara parsial berpengaruh positif terhadap manajemen laba yang diproksikan dengan discretionary accruals. Meningkatnya kepemilikan manajerial menyebabkan ikut meningkatnya earning mangement, dan sebaliknya penurunan kepemikan manajerial cendrunga akan menyebakan menurunnya earning management, sehingga dapat disimpulkan $\mathrm{H} 1$ diterima.

\section{Pengaruh Kepemilikan Institusional Terhadap Manajemen Laba}

Hasil analisis regresi linier berganda diperoleh beta sebesar - 0.438 dengan sebesar - 1.540 dan nilai signifikansi sebesar 0.135. Karena $\left|t_{\text {hitung }}\right|>t_{\text {tabel }}>(3.236$ $>1.701)$ dengan nilai signifikansi $>5 \%(0.135>0.05)$, maka dapat diartikan bahwa variabel kepemilikan institusional tidak berpengaruh secara parsial terhadap discretionary accruals yang merupakan proksi dari earning management. Meningkat atau menurunnya kepemilikan institusional tidak akan mempengaruhi earning management, maka dapat disimpulkan $\mathrm{H} 2$ ditolak.

\section{Pengaruh Dewan Komisaris Independen Terhadap Manajemen Laba}

Hasil analisis regresi linier berganda diperoleh beta sebesar -0.378 dengan sebesar -0.733 dan nilai signifikansi 0.446. Dari hasil $t_{\text {hitung }} \mid>t_{\text {tabel }}>(-0.733<$ 1.701) dengan nilai signifikansi $>5 \%(0.446>0.05)$, maka dapat diartikan bahwa variabel dewan komisaris independen tidak berpengaruh secara parsial terhadap variabel manajemen laba yang diproksikan dengan discretionary accruals. Meningkat atau menurunnya dewan komisaris independen tidak akan mempengaruhi earning management, sehingga dapat disimpulkan $\mathrm{H} 3$ ditolak

\section{Pengaruh Komite Audit Independen Terhadap Manajemen Laba}

Hasil analisis regresi linier berganda diperoleh beta sebesar -0.233 dengan sebesar -1.022 dan nilai signifikansi 0.315. Dari hasil $t_{\text {hitung }} \mid>t_{\text {tabel }}>(-1.022<$ 1.071) dengan nilai signifikansi $>5 \%(0.315>0.05)$, maka dapat diartikan bahwa variabel komite audit independen tidak berpengaruh secara parsial terhadap variabel manajemen laba yang diproksikan dengan discretionary accruals. Meningkat atau menurunnya komite audit independen tidak akan mempengaruhi earning management, sehingga dapat disimpulkan $\mathrm{H} 4$ ditolak.

\section{SIMPULAN}

Berdasarkan hasil analisis data dan pembahasan yang telah dikemukakan pada bab IV, maka dapat ditarik kesimpulan bahwa:

1. Dari hasil pengujian regresi menunjukkan bahwa kepemilkan manajerial berpengaruh signifikan positif terhadap besar kecilnya praktik discretionary accruals (manajemen laba) di suatu perusahaan.

2. Dari hasil pengujian regresi menunjukkan bahwa kepemilkan institusional tidak berpengaruh signifikan terhadap besar kecilnya discretionary accruals (manajemen laba)di suatu perusahaan.

3. Hasil analisis regresi membuktikan bahwa prosentase komisaris independen tidak berperngaruh signifikan terhadap besar kecilnya discretionary accruals (manajemen laba)di suatu perusahaan. 
4. Hasil analisis regresi menunjukkan bahwa prosentase komite audit independen tidak berpengaruh signifikan terhadap besar kecilnya discretionary accruals (manajemen laba) di suatu perusahaan.

\section{KETERBATASAN DAN SARAN}

Pada penelitian ini masih ada keterbatasan yang menghambat selama penelitian dilakukan. Diharapkan dengan adanya keterbatasan ini peneliti selanjutnya mampu mengatasi agar hasil penelitian yang dilakukan lebih maksimal sesuai dengan yang diharapkan peneliti.

1. Jumlah sampel yang terlalu sedikit karena ada berbagai faktor yang tidak sesuai dengan kriteria yang telah ditentukan.

2. Penelitian ini menggunkan sampel perusahaan, baik yang terindikasi earnings management maupun yang tidak terindikasi melakukan earnings management sehingga tidak menggambarkan dengan baik bagaimana dampak penerapan good corporate governance.

3. Perusahaan manufaktur yang terdaftar di CGPI pada periode penelitian masih sedikit yang merupakan BUMS dan banyak yang merupakan lembaga keuangan sehingga banyak perusahaan yang dikeluarkan dari populasi.

Berdasarkan kesimpulan dan keterbatasan dalam penelitian, peneliti memberikan beberapa saran berkaitan dengan penelitian yang telah dilakukan. Saran-saran tersebut antara lain:

1. Bagi penelitian selanjutnya

Menambahkan variabel lain dalam penelitian yang dipandang lebih dapat mempengaruhi earnings management, misalnya menggunakan ukuran dewan direksi dan kualitas audit. Peneliti selanjutnya dapat menambahkan periode pengambilan data sebelum dan sesudah perusahaan terdaftar di CGPI, sehingga didapatkan hasil yang maksimal dan akurat dalam penelitian yang dilakukan. Memperluas objek penelitian yang dilakukan untuk menghasilkan penelitian yang lebih luas dari penelitian ini.

2. Bagi Organisasi/Perusahaan

Perusahaan diharapkan meningkatkan kualitas tata kelola seperti peningkatan proporsi komisaris independen dan memberikan kesempatan kepada manajer untuk memiliki saham di perusahaan. Selain itu perusahaan juga perlu memilih manajer yang memiliki etika yang baik karena walaupun dengan standar yang tinggi earnings management dapat dilakukan jika manajer memiliki niat yang tidak baik.

\section{DAFTAR PUSTAKA}

Abdullah, H., dan Benedict, V. (2009). "Fundamental and Ethics Theories of Corporate Governance”. Middle Eastern Finance and Economics. 4. 88-96.

Armein, R. A. (2005). "Analisis Kasus Laporan Keuangan PT. Indofarma Tbk", Jurnal law review. 3 (4). 239-245

Borlea, N., dan Monica, V. (2013). "Theories Of Corporate Governance”. Economic series. $23(1) .117-126$

Butar, S. B. (2013)" Pengaruh Karakteristik Dewan Komisaris dan Kepemilikan Institusional Terhadap Manajemen Laba Berbasis Aktivitas Real". Jurnal Akuntansi Bisnis. 12 (23) 
Pengaruh

Mekanisme

Good

Corporate...

1078
Chotourou, S.M., Bedard, J., dan Courteau, L. (2001). "Corporate Governance and Earning Management”. Desember

Ghozali, I. (2016). Aplikasi analisis multivariete. Semarang: Badan Penerbit Universitas Diponogoro

Guna. I. W. dan Arleen, H. (2010). "Pengaruh Mekanisme Good Corporate Governance, Independensi Auditor, Kualitas Audit dan Faktor Lainnya Terhadap Manajemen Laba”. Jurnal Akuntansi dan Manajemen. 1 (12). 53-68

Hazri, M., dan Sugiyarti, F.L. (2012). "Pengaruh Mekanisme Good Corporate Governance Terhadap Praktik Manajemen Laba: Studi Pada Perusahaan Yang Termasuk Dalam CGPI”. Tazkia Islamic Finance and Business. 37-49

Hessayri, M. \& Saihi, M. 2015. Monitoring earnings management in emerging markets. Journal of Economic and Administrative Sciences, 31(2). Tersedia di http://www.emeraldinsight.com/doi/10.1108/JEAS-11-2014-0029 Review. 7 (1). 37- 49

IICG (2013). "Laporan Hasil Riset dan Pemeringkatan”. Corporate Governance Perception Index

IICG (2014). "Laporan Hasil Riset dan Pemeringkatan”. Corporate Governance Perception Index

IICG (2015). "Laporan Hasil Riset dan Pemeringkatan". Corporate Governance Perception Index

Indriana, K., dan Leni, R. (2016). "Menganalisis Kasus Manajemen Laba Yang Ada di Indonesia (PT. Great River Internasional tbk)", Tugas Analisis Laporan Keuangan.

Laporan Bank Indonesia. (1998-1999)

Laporan Komite Cadbury (1992). "The Financial Aspect of Corporate Governance". Desember

Luthan, E., Illeh, S., dan Ilmainir (2016). "The Effect of Corporate Governance Mechanism to Earnings Management Before and After IFRS Convergence". $3^{\text {rd }}$ Global Converence on Business and Social Science 2015. 219.465-471

Maksum, A. (2005). "Tinjauan Atas Good Corporate Governance di Indonesia". pidato pengukuhan jabatan guru besar tetap. Hal 2-3

Marpaung, C. O., Ni, M. Y. L. (2014). "Pengaruh Dewan Komisaris Independen, Komite Audit, Kualitas Audit dan Kepemilikan Manajerial Pada Perataan Laba”. Jurnal Akuntansi Udayana. 7(2). 279-289

Masdupi, E. (2012). "Pengaruh Insider Ownership, Struktur Modal, dan Pertumbuhan Perusahaan Terhadap Kebijakan Dividen Perusahaan Syariah yang Terdaftar di Bursa Indonesia”. Jurnal Ekonomi. 1 (12). 9-14.

Midiastuty, P., dan Mas'ud Machfoedz. 2003. "Analisis Hubungan Mekanisme Corporate Governance dan Indikasi Manajemen Laba". Simposium Nasional Akuntansi VI.

Pasaribu, R. B. F., et al. (2015).” Mekanisme Good Corporate Governance, Ukuran Perusahaan, Struktur Kepemilikan Manajerial dan Leverage pada Manajemen Laba pada Emiten Perbankan di Bursa Efek Indonesia”. Jurnal Riset Manajemen dan Bisnis. 1 (10). 1-22

Peraturan Otoritas Jasa Keuangan Nomor 55/POJK.04/2015. "Tentang Pembentukan dan Pedoman Pelaksanaan Kerja Komite Audit”

Peraturan Otoritas Jasa Keuangan nomor 33/POJK.04/2014. "Tentang Direksi dan Dewan Komisaris Emiten Atau Perusahaan Publik"

Peraturan Bank Indonesia Nomor 8/14/2006. “Tentang Peraturan GCG Bagi bank umum"

Porter, M.E. 1992. Capital choices: Changing the way America invests in industry. Journal of Applied Corporate Finance, 5(2): pp.4-16. 
Praditia, Okta Rezika. 2010. "Analisis Pengaruh Mekanisme Corporate Governance Terhadap Manajemen Laba Dan Nilai Perusahaan Pada Perusahaan Manufaktur Yang Terdaftar Di Bursa Efek Indonesia (Bei) Pada Tahun 20052008 ".

Reviani, D.. dan Djoko, S. (2012), "Pengaruh Struktur Kepemilikan, Ukuran Perusahaan, dan Corporate Governance Terhadap Manajemen Laba". Jurnal prestasi. 9 (1). 92-108

Sulistyanto, S., dan Haris, W. (2003). "Good Corporate Governance: Berhasilkah Diterapkan di Indonesia”. Jurnal Widya Warta. 26 (2).

Sari, P. K., dan Fakhruddin (2016). "Identifikasi Penyebab Krisis Moneter dan Kebijakan Bank Sentral di Indonesia: Kasus Krisis Tahun (1997-1998 dan 2008)". Jurnal Ilmiah Mahasiswa. 2 (1) 378-384

Sari, S. R., dan Nur, F. A. (2013). "Pengaruh Leverage dan Mekanisme Good Corporate Governance Terhadap Manajemen Laba". Jurnal Ilmu dan Riset Akuntansi. 6 (2). 1-21

Tanjung, M., Sucherly., Sutisna., dan Rahmat, S. (2015). "The Role Of Good Corporate Governance In Minimazing Earning Management To Increase Value Of Firm". International Jurnal Of Scientific and Tecnology Research. 9 (4). 21-27

Ujiyantho, M. A. dan Bambang, A. P. (2007). "Mekanisme Good Corporate Governance, Manajemen Laba dan Kinerja Keuangan”. Simposium Nasional Akuntansi X

Wedari, L. K. (2004). "Analisis Pengaruh Proporsi Dewan Komisaris dan Keberadaan Komite Audit Terhadap Manajemen Laba”. Simposium Nasional Akuntansi VII

Widyaningdyah, A. U. (2001). "Faktor-Faktor yang Berpengaruh Terhadap Earning Management Pada Perusahaan yang Go Publik di Indonesia". Jurnal Akuntansi dan Keuangan. 2 (3). 89-101

http://www.bpkp.go.id/dan/konten/299/Good-Corporate.bpkp (diakses 4 Mei 2017) www.iicg.org

https://www.merdeka.com/uang/nilai-tukar-rupiah-saat-ini-cuma-beda-rp-3000dibanding-krisis-1998.html (diakses 2 Mei 2017)

http://www.suaramerdeka.com/harian/0302/24/eko1.html (diakses 4 Mei 2017)

http://www.fcgi.or.id/corporate-governance/about-good-corporate governance.html (diakses 4 Mei 2017)

http://www.nytimes.com/2001/12/04/business/enron-s-collapse-investors-plentypain-go-around-for-small-investors-funds.html (diakses 18 Mei 2017) 
